\title{
Controlling crop disease contributes to both food security and climate change mitigation
}

M. Mahmuti ${ }^{1}$, J.S.West ${ }^{1}$, J.Watts ${ }^{2}$, P. Gladders ${ }^{3}$ and B.D.L. Fitt ${ }^{1 *}$

${ }^{1}$ Rothamsted Research, Harpenden, Hertfordshire AL5 2JQ, UK

2 HGCA, Agriculture and Horticulture Development Board, Stoneleigh Park, Kenilworth, Warwickshire, CV8 2TL, UK

${ }^{3}$ ADAS Boxworth, Battlegate Road, Boxworth, Cambridgeshire CB23 4NN, UK

* Corresponding author. Email: bruce.fitt@bbsrc.ac.uk 


\begin{abstract}
Global food security is threatened by crop diseases that account for average yield losses of $16 \%$, with the greatest losses experienced by subsistence farmers in the developing world. Climate change is exacerbating the threats to food security in such areas, emphasising the need to increase food production in northern European countries such as the UK. However, the crops must be grown in such a way as to minimise greenhouse gas emissions (GHG) associated with their production. As an example, it is estimated that production of UK winter oilseed rape is associated with GHG of $3300 \mathrm{~kg} \mathrm{CO} 2$ eq. ha-1 of crop and $834 \mathrm{~kg} \mathrm{CO}_{2}$ eq. $\mathrm{t}^{-1}$ of seed yield, with $79 \%$ of the GHG associated with the use of nitrogen fertiliser. Furthermore, it is estimated that control of diseases by use of fungicides in this UK oilseed rape is associated with a decrease in $\mathrm{GHG}$ of $100 \mathrm{~kg} \mathrm{CO}_{2}$ eq. $\mathrm{t}^{-1}$ of seed. Winter oilseed rape cultivar disease resistance is associated with a decrease in $\mathrm{GHG}$ of $56 \mathrm{~kg} \mathrm{CO}_{2}$ eq. $\mathrm{t}^{-1}$, although this figure is an underestimate. These results demonstrate how disease control in arable crops can make a contribution to both climate change mitigation and sustainable arable crop production to ensure global food security.
\end{abstract}

Keywords: adaptation to climate change, disease resistance, food security, fungicides, greenhouse gas emissions, oilseed rape 


\section{Introduction}

Crop diseases directly threaten global food security. Food security is defined as the situation when there is sufficient food to eat to meet dietary needs for an active, healthy life, and may be considered at the global, national, community or household level (Schmidhuber \& Tubiello, 2007; Pinstrup-Andersen, 2009). However, worldwide more than 800 million people do not have sufficient food (Strange \& Scott, 2005). The effects of diseases mean that there is less food to eat due to crop losses, estimated at $16 \%$ globally despite efforts to control the diseases (Oerke, 2006). Consequently, there is a need to increase food production by controlling crop diseases more effectively. It is preferable to increase global food production by decreasing losses rather than by increasing crop areas through destroying natural ecosystems such as rain forests. The food security problems associated with crop diseases are especially acute in the developing world, where crops can be destroyed, leading to starvation and death for subsistence farming families (Strange \& Scott, 2005). The food security problems associated with crop diseases are now being made more acute by climate change (Chakraborty et al,. 2000; Garrett et al., 2006). Whilst the severe consequences of climate change for food security due to sea-level rise, desertification, drought and heat-stress are widely recognised (FAO, 2007, 2009; Frow et al., 2009), the importance of including crop diseases in climate change impact assessments is not (Gregory et al., 2009). Climate change may increase the severity and range of existing crop diseases (Evans et al., 2008) or lead to the introduction of new diseases (Anderson et al., 2004).

Since the threats of climate change to food security are particularly severe for farmers in subsistence agriculture in marginal areas such as sub-Saharan Africa (Morton, 2007, Schmidhuber \& Tubiello, 2007), there will be increased pressure on farmers in fertile areas that may benefit from climate change, such as northern Europe (Butterworth et al., 2009), to produce more food at high yields to guarantee global food security (Stern, 2007). To do this, it will be essential to include strategies to control existing and new disease problems into strategies for adaptation to impacts of climate change (Evans et al., 2008; Gregory et al., 2009). Thus there is a necessity to maintain or increase food production in northern European countries such as the UK, whilst growing crops in such a way as to decrease emissions of greenhouse gases 
(GHG) as a contribution to climate change mitigation. Agriculture makes an important contribution to GHG emissions; for example, GHG from agriculture account for $7 \%$ of the total GHG produced in the UK (Jackson et al., 2007). To decrease the contribution of agriculture to global warming, there are many possible options (Smith et al., 2007, 2008; Gregory, 2008). These include decreasing the use of fossil fuels and nitrogen fertilisers (and consequential production of $\mathrm{N}_{2} \mathrm{O}$ ), decreasing methane emissions from livestock and increasing the sequestering of carbon from the atmosphere (Glendining et al., 2008).

This paper investigates the contribution to this climate change mitigation objective, from disease control in arable crops through fungicide treatment and cultivar resistance. There is already evidence that disease control in UK winter wheat crops can contribute to climate change mitigation (Berry et al., 2008). In this paper, we examine the effects of disease control on UK winter oilseed rape in relation to GHG emissions. It is assumed that there is a need to sustain the UK production of winter oilseed rape at the levels recorded (Anonymous, 2008b) for the four years studied. Worldwide production of oilseed rape is 50Mt per annum (www.fas.usda.gov), worth $£ 15000 \mathrm{M}$ at a price of $£ 300 / \mathrm{t}$. The main diseases that affect the UK winter oilseed rape crop are phoma stem canker (Leptosphaeria maculans) and light leaf spot (Pyrenopeziza brassicae), which cause annual losses worth more than £550M worldwide (Fitt et al., 2006, 2008).

\section{Methods}

\section{Datasets}

The main datasets used were obtained from the HGCA Recommended List trial harvest results for the harvest years 2004 to 2007 (Anonymous, 2008a). Trials were at sites throughout England and Scotland. Although many of the trials could provide data for yields of different cultivars that had been sprayed with fungicide, fewer trials included additional untreated plots. To assess the effects of controlling disease on yield, the data considered came only from trials where both fungicide-treated and untreated plots were grown. Additional datasets included yield information for fungicide-treated and untreated plots from field experiments done at Rothamsted 
(2005, 2006, 2007) or by ADAS (at Teversham in 2005 and Boxworth in 2006 and 2007) for the CORDISOR project (West et al., 2008).

\section{GHG emissions for 1 ha of winter oilseed rape}

GHG emissions were calculated for the production of 1 ha of winter oilseed rape in the UK (Fig. 1, Table 1) in a similar way to calculation of GHG production of 1 ha of winter wheat by Berry et al. (2008). The global warming potential (GWP) resulting from emissions of $\mathrm{CO}_{2}, \mathrm{~N}_{2} \mathrm{O}$ and $\mathrm{CH}_{4}$ was calculated in terms of the equivalent GWP of $\mathrm{CO}_{2}$ (kg eq.). For example, $1 \mathrm{~kg}$ of $\mathrm{N}_{2} \mathrm{O}$ is assumed to have a GWP 298 times greater than $1 \mathrm{~kg}$ of $\mathrm{CO}_{2}$ (De Klein et al., 2006). The GHG emissions for the production of 1 ha of winter oilseed rape were calculated by examining the application rates $(\mathrm{kg} / \mathrm{ha}, \mathrm{MJ} / \mathrm{ha})$ of different inputs associated with the production of the crop. For winter oilseed rape, these inputs include agro-chemicals such as fungicides, insecticides and herbicides, fertilisers such as nitrogen, potash and phosphate and soil conditioners such as lime. Additional contributing inputs include the energy used in the production of the seed for sowing and in field operations (e.g. tractor use for cultivation and application of agro-chemicals and harvesting operations).

(Fig. 1, Table 1 near here)

A 6-year mean (2002-2007) of the application rate ( $\mathrm{kg} / \mathrm{ha})$ was estimated for the fertilisers and lime (Anonymous, 2007a). A 4-year mean of the application rate (kg/ha) for pesticides (Garthwaite et al., 2006) was calculated using the years 1996, 2002, 2004 and 2006. Calculations for emissions due to liming were based on the use of ground limestone as the liming material because it is more cost-effective and more frequently used than other alternative materials (Anonymous, 2000). The emissions associated with nitrogen fertilisers included not only those associated with its manufacture but also those from nitrogen oxides such as $\mathrm{N}_{2} \mathrm{O}$ which are produced when applied nitrogen breaks down in the soil. The average application rate for nitrogen was approximately $202 \mathrm{~kg} / \mathrm{ha}$. The emission factor for the manufacture of ammonium nitrate (nitrogen fertiliser) was estimated to be $7.11 \mathrm{~kg} \mathrm{CO}_{2}$ eq. $\mathrm{kg}^{-1}$ (Anonymous, 2007b) and that for release of nitrogen oxides when the fertiliser is applied was estimated to be $6.16 \mathrm{~kg} \mathrm{CO}_{2}$ eq. $\mathrm{kg}^{-1}$ (De Klein et al., 2006). 
The energy use for field operations was considered in terms of conventional plough and reduced-tillage systems of cultivation. The plough system takes into account sub-soiling, ploughing, power harrowing, discing and packing, conventional drilling, Cambridge rolling, self-propelled spraying, swathing/desiccant and lime spreading. The reduced-tillage system includes sub-soiling, discing, power harrowing, combination drilling, Cambridge rolling, self-propelled spraying and swathing/desiccant use. Swathing and desiccant use were assumed to require approximately the same amounts of energy. The rates at which these operations were done were then applied to both systems and the total energy used for each system was calculated. The energy use for the plough system was $5556 \mathrm{MJ} \mathrm{ha}^{-1}$ whereas the energy use in a reduced-tillage system was $4701 \mathrm{MJ} \mathrm{ha}^{-1}$ (Williams et al., 2006); the average value $5129 \mathrm{MJ} \mathrm{ha}^{-1}$ was used in these calculations.

Consequently the total GHG emissions for 1 ha of winter oilseed rape was calculated as the sum of all the GHG emitted by the inputs applied in the production process:

$\mathbf{G H G}_{\boldsymbol{h a}}=\left(\mathrm{N}_{\text {manuf }}+\mathrm{N}_{\text {soil }}\right)+\mathrm{P}_{2} \mathrm{O}_{5}+\mathrm{N}_{2} \mathrm{O}+\mathrm{K}_{2} \mathrm{O}+$ Lime + Fungicides + Herbicides + Insecticides + Field Ops.

\section{GHG emissions for production of 1 t of seed}

The GHG emissions for production of $1 \mathrm{t}$ of seed were calculated by using the equation:

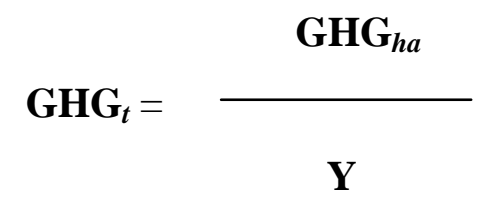

Here the $\mathbf{G H G}_{t}$ are the greenhouse gas emissions associated with production of $1 \mathrm{t}$ of oilseed rape. $\mathbf{G H G}_{\boldsymbol{h} \boldsymbol{a}}$ represents the emissions associated with the production of 1 ha of winter oilseed rape and $\mathbf{Y}$ is the yield obtained under different crop-protection scenarios considered. The seed was considered to be the only part of winter oilseed rape to be harvested since at present no market exists for rapeseed straw (Booth et al., 2005). Some straw may be used on farm for animal bedding, but it is a poorer 
bedding material than cereal straw and it is rarely traded (Booth et al., 2005). Winter oilseed rape straw contains nitrogen, which is available, following decomposition, for the next crop. However, this residual nitrogen was not included in these calculations, since it does not directly affect the benefits from disease control in the current winter oilseed rape crop. The relationship between GHG emissions per tonne and yield per hectare was then estimated by using different yield values, from 1 to $6 \mathrm{t} \mathrm{ha}^{-1}$. The seed yield was the only parameter changed while other inputs were kept constant. The yield values were subsequently entered into equation (2).

\section{Effects of fungicide treatment}

To estimate the effect of fungicides to control disease on the emissions per tonne of seed, the differences in yields between fungicide-treated and untreated plots in experiments throughout the UK were analysed. The means of the data for specific years were calculated for every cultivar in the sites where plots with and without fungicides had been grown. By using equation (2), the different amounts of GHG emitted per tonne of seed produced when fungicides were/were not used were estimated. This process was applied to data from HGCA trials and those done by Rothamsted and ADAS. The period used for the HGCA data was harvest years 2004 to 2007, while the Rothamsted and ADAS data were for the years 2005 to 2007 . In the case of the HGCA data, the numbers of cultivars used differed in the four years; 26 (2004), 39 (2005), 24 (2006), 29 cultivars (2007). Such variations resulted from the addition or the removal of cultivars to the list of cultivars for testing in the UK Recommended List trials. The Rothamsted and ADAS experiments included 20 cultivars in 2005 to 2007 (19 in 2005 at Rothamsted). The same 20 cultivars were used each year except for cv. Aragon, which was replaced by cv. Es-Astrid after 2005.

\section{Effects of cultivar resistance}

To evaluate the effectiveness of disease resistance for mitigating climate change, differences in yield between cultivars of winter oilseed rape that were resistant or susceptible to two pathogens, Leptosphaeria maculans (cause of phoma stem canker) and Pyrenopeziza brassicae (cause of light leaf spot) were obtained from HGCA trial data. It was also necessary to take into account the different geographical ranges of 
phoma stem canker (south) and light leaf spot (north) to better assess whether differences in yield between cultivars were attributable to resistance rather than other factors. The HGCA Recommended List of cultivars (Anonymous, 2008a) divides the UK into two regions in relation to the predominant disease and other factors. These are the 'north' region, comprising Scotland and northern England (north of a line from Lancaster in the west to Middlesbrough in the east) and the 'south' region, which comprises Wales and England south of the line from Lancaster to Middlesbrough (Anonymous, 2008a). The north region suffers substantial crop losses from light leaf spot, whilst phoma stem canker is almost absent, while the south region has substantial losses from phoma stem canker but little light leaf spot (www.cropmonitor; Boys et al., 2007; West et al., 2008). The effects of disease resistance on GHG emissions per tonne of yield were therefore based on data for each disease only from the relevant region.

Then the HGCA Recommended List resistance ratings of the cultivars, assessed from their trial disease scores, where 1 is very susceptible and 9 is resistant to the pathogen, were used to divide the cultivars into resistant and susceptible groups. For light leaf spot ( $P$. brassicae), the cultivars with ratings 7-9 were considered resistant and those with ratings 1-6 susceptible. For phoma stem canker (L. maculans), cultivars with resistance ratings 6-9 were considered resistant and 1-5 susceptible. The cultivars were thus grouped because there was a need to provide an equivalent number of cultivars in each group so that the two groups could be compared. The mean yield of these 'resistant' and 'susceptible' cultivars was then calculated separately for fungicide-treated and untreated plots for different HGCA sites where data were collected in the harvest years 2004-2007. The mean values were then inserted into equation (2) to calculate the differences in GHG emissions per tonne of seed produced by cultivars with more/less resistance to P. brassicae or L. maculans.

The numbers of northern HGCA sites used in each year for assessing the effect of cultivar resistance to P. brassicae were 3 (2004), 3 (2005), 2 (2006) and 1 (2007). The numbers of susceptible cultivars were 8 (2004), 10 (2005), 13 (2006) and 16 (2007), whereas the numbers of resistant cultivars were 9 (2004), 10 (2005), 5 (2006) and 4 (2007). The numbers of southern HGCA sites used for each year for assessing the effect of cultivar resistance to L. maculans were 2 (2004), 4 (2005), 4 (2006) and 3 (2007). The numbers of susceptible cultivars were 6 (2004), 11 (2005), 14 (2006) 
and 16 (2007), whereas the numbers of resistant cultivars were 13 (2004), 9 (2005), 5 (2006) and 4 (2007).

\section{Economic evaluation}

The gross margin (profitability) analysis and other economic assessments were based on weekly updated prices, the annual mean of which was used as the base price for each year. These prices $(£ / t)$ were obtained from MATIF SA (Marché à Terme International de France), the French futures exchange. The current (2009) price of $£ 294 / t$ was based on the Nov 2009 rapeseed futures price ( $€ 386$, exchange rate $€ 1$ $=£ 0.814)$. The fixed input cost of $£ 495$ per hectare was calculated as the average price for 2004-2007 for fertilisers (nitrogen, potash, and phosphate), chemicals (pesticides) and seed, taken from the editions of the Farm Management Pocketbook for the period 2004-2007 (Nix, 2004-2007). The application rates used for fertilisers (Anonymous, 2007a) and pesticides (Garthwaite et al., 2006) were based on averages of 6 years (2002-2007) and 4 years $(1996,2002,2004,2006)$, respectively. The harvest estimates include both winter and spring sown oilseed rape. The UK total production increased from 1,607 Mt of seed in 2004 to 1,897Mt (2005), 1890 (2006) and 2,108 Mt (2007) (Anonymous, 2008b). These economic calculations of the impact of fungicides make assumptions that the price was unaffected by the changes in supply of oilseed rape due to disease and that the opportunity cost or value of the best foregone choice when choosing the crop can be ignored.

We estimated the land area (ha) required to sustain UK winter oilseed rape production at the 2007 level (Anonymous, 2008b), if the crop had been fungicideuntreated, by using the percentage yield loss figure for each specific year (HGCA trials 2004-2007). The percentage yield loss was calculated by taking the mean data for each year for fungicide-treated and untreated crops and calculating the percentage of yield lost. The data considered were only from trials with both fungicide-treated and untreated plots. The difference in land area needed for the same UK production between scenarios where crops were all fungicide-treated and where crops were untreated was then calculated by subtraction. The nominal UK financial losses were estimated using yearly winter oilseed rape production values (Mt), the prices for the specific year ( $£$ average physical delivered prices throughout the UK; 
data.hgca.com/demand/physical.asp) and the average percentage of crop lost to disease each year. The financial losses were then adjusted for inflation (UK Consumer Price Index as the chosen price index) to calculate their real value.

\section{Results}

\section{Predicted GHG emissions per hectare of winter oilseed rape}

The production of 1 ha of winter oilseed rape was estimated to release emissions of $3337 \mathrm{~kg} \mathrm{CO}$ eq. This estimate is similar to the estimate of $3285 \mathrm{~kg} \mathrm{CO}_{2}$ eq. calculated by Spink et al. (2009). The most substantial contribution to GHG emitted during the production and harvesting of winter oilseed rape was associated with the use of fertilisers, which accounted for $85 \%$ of all emissions. Nitrogen fertiliser accounted for $79 \%$ all of emissions (manufacture, $1433 \mathrm{~kg} \mathrm{CO}_{2}$ eq. and $\mathrm{N}_{2} \mathrm{O}$ released after application, $1242 \mathrm{~kg} \mathrm{CO}$ eq.) (Fig. 2). Another large contributor to GHG emissions was field operations, which were associated with $443 \mathrm{~kg} \mathrm{CO}_{2}$ eq. (14\% of the total). The conventional plough system was estimated to release $480 \mathrm{~kg} \mathrm{CO}_{2}$ eq. while a reduced-tillage system accounted for $406 \mathrm{~kg} \mathrm{CO}_{2}$ eq. Use of crop protection chemicals contributed emissions of approximately $9.4 \mathrm{~kg} \mathrm{CO}_{2}$ eq. $(0.3 \%$ of the total), with emissions associated with fungicides, herbicides and insecticides estimated to be $1.37 \mathrm{~kg} \mathrm{CO} 2$ eq. ( $<0.1 \%$ of the total), $7.89 \mathrm{~kg} \mathrm{CO} 2$ eq. and $0.15 \mathrm{~kg} \mathrm{CO}_{2}$ eq., respectively. Using a UK winter oilseed rape crop area of for the harvest year 2007 of 608,000 ha (not including 73,000 ha for industrial use) from official government estimates (Anonymous, 2008b), this gives an estimate of total UK winter oilseed rape emissions of $2.03 \mathrm{Mt} \mathrm{CO}_{2}$ eq. This increases to $2.27 \mathrm{Mt}$ if it is assumed that inputs to the 73,000 ha of industrial winter oilseed rape are similar to those for oilseed rape for food-use.

(Fig. 2 near here)

\section{Predicted GHG emissions per tonne of seed}


The GHG produced per tonne of winter oilseed rape seed produced, calculated using an average yield of $4 \mathrm{t} \mathrm{ha}^{-1}$ (mean of fungicide-treated and untreated plots, HGCA data), were estimated to be $834 \mathrm{~kg} \mathrm{CO}_{2}$ eq. As the yield of the seed increased, the GHG emissions per tonne of seed produced decreased (Fig. 3). The difference in GHG emissions per tonne of seed between yields of 1 and $3 \mathrm{t} \mathrm{ha}^{-1}$ was $2225 \mathrm{~kg} \mathrm{CO}_{2}$ eq. $\mathrm{t}^{-1}$. While the low yield of $1 \mathrm{t} \mathrm{ha}^{-1}$ might be considered unrealistic for the UK, it should not be ignored in an international context since winter oilseed rape yields are less in countries such as Australia or Canada, although inputs are also less.

(Figure 3 here)

\section{Effects of fungicide treatment}

There were in total 627 units of yield data comparing fungicide treated and untreated crops in the HGCA Recommended List trials during the period with harvest years 2004-2007; these data included a range of sites in England and Scotland and a range of cultivars differing in their resistance to the two pathogens. The 4-year mean yields were $4.33 \mathrm{t} \mathrm{ha}^{-1}$ for fungicide-treated winter oilseed rape and $3.84 \mathrm{t} \mathrm{ha}^{-1}$ for untreated crops. The difference of $0.49 \mathrm{t} \mathrm{ha}^{-1}$ provides an estimate of the disease-induced yield loss for all cultivars, irrespective of their resistance to the pathogens. It represents a loss of approximately $11.3 \%$ of the fungicide-treated winter oilseed rape yield. This difference was associated with a net increase in emissions of $98 \mathrm{~kg} \mathrm{CO}_{2}$ eq. $\mathrm{t}^{-1}$ for winter oilseed rape produced without fungicide treatments by comparison to fungicide-treated crops. This estimate of the mean increase in emissions per tonne of yield was based on the differences in yields for each year, which resulted in increases in emissions ranging from $121 \mathrm{~kg} \mathrm{CO}_{2}$ eq. $\mathrm{t}^{-1}$ in 2004 to $77 \mathrm{~kg} \mathrm{CO}_{2}$ eq. $\mathrm{t}^{-1}$ in 2007 (Fig. 4). In the Rothamsted experiments, the differences in emissions ranged from 93 $\mathrm{kg} \mathrm{CO}$ eq. $\mathrm{t}^{-1}$ in 2005 to $221 \mathrm{~kg} \mathrm{CO}_{2}$ eq. $\mathrm{t}^{-1}$ in 2007 (Fig. 5). In the ADAS experiments, the greatest and smallest increases in emissions per tonne were $97 \mathrm{~kg}$ $\mathrm{CO}_{2}$ eq. $\mathrm{t}^{-1}$ in 2005 and $72 \mathrm{~kg} \mathrm{CO}_{2}$ eq. $\mathrm{t}^{-1}$ in 2006, respectively (Fig. 5). The annual means for these differences in emissions were therefore $101 \mathrm{~kg} \mathrm{CO}_{2}$ eq. $\mathrm{t}^{-1}$ for the HGCA trials, $169 \mathrm{~kg} \mathrm{CO}$ eq. $\mathrm{t}^{-1}$ for Rothamsted and $82 \mathrm{~kg} \mathrm{CO}_{2}$ eq. $\mathrm{t}^{-1}$ for ADAS experiments. Disease control in winter oilseed rape generally decreased GHG 
emissions more than disease control in winter wheat, which decreased them by $60 \mathrm{~kg}$ $\mathrm{CO} 2$ eq. $\mathrm{t}^{-1}$ (Berry et al., 2008). Nevertheless, these calculations underestimate the potential climate change mitigation benefits of disease control since the fungicide treatments did not provide complete control of the diseases and disease epidemics can be much more severe than those occurring in these experiments.

(Figures $4 \& 5$ here)

The UK average yield per hectare on commercial farms (3.13 $\mathrm{tha}^{-1}$ ) (Anonymous, $2008 \mathrm{~b})$ was $1.2 \mathrm{t} \mathrm{ha}^{-1}$ less than the average yield of fungicide-treated plots $\left(4.33 \mathrm{t} \mathrm{ha}^{-1}\right)$ in these HGCA winter oilseed rape trials for harvest years 2004 to 2007. In the HGCA trials, the annual percentages of crop lost to diseases ranged from 9.1\% in 2007, $9.3 \%$ (2006), $13.3 \%$ (2005) to $13.9 \%$ (2004). Assuming that the average percentage loss in yield from diseases in UK commercial winter oilseed rape crops was similar to that in the trials in each of the years and that crops were treated with fungicides, the average difference in GHG emitted between fungicide-treated and untreated commercial crops for these years was greater (i.e. $130 \mathrm{CO}_{2}$ eq. $\mathrm{t}^{-1}$ ) than in the HGCA trials (98 kg CO 2 eq. $\mathrm{t}^{-1}$ of seed produced). Assuming a requirement to maintain $\mathrm{UK}$ production for 2007 at $2.1 \mathrm{M} \mathrm{t}$ (Anonymous, 2008b), the total GHG emissions from the production of $\mathrm{UK}$ winter oilseed rape in 2007 were estimated to be $2.27 \mathrm{Mt} \mathrm{CO}_{2}$ eq2. when the crops were sprayed with fungicides and $2.50 \mathrm{Mt} \mathrm{CO}_{2}$ eq. when fungicides were not used. This represents a saving of $0.23 \mathrm{Mt} \mathrm{CO}_{2}$ eq. for the year. Savings of $0.20 \mathrm{Mt} \mathrm{CO}_{2}$ eq. (2006), 0.30 $\mathrm{Mt} \mathrm{CO}_{2}$ eq. (2005) and $0.30 \mathrm{Mt} \mathrm{CO}_{2}$ eq. (2004) were estimated for the other years, using the respective UK production levels (1.89 Mt in 2006, 1.9 Mt in 2005 and 1.61Mt in 2004) (Anonymous, 2008b). This is an average saving of $0.26 \mathrm{Mt} \mathrm{CO}_{2}$ eq. per annum over this period.

For comparative purposes, if the UK production of winter oilseed rape was considered to be $15 \mathrm{Mt}$ (i.e. the same as the UK wheat production; Anonymous, $2008 \mathrm{~b}$ ), the 4-year average yield to be $3.13 \mathrm{t} \mathrm{ha}^{-1}$ (Anonymous, 2008b) and the percentage lost to disease $11.3 \%$, the net carbon emission savings would be $2 \mathrm{Mt} \mathrm{CO}_{2}$ eq. if the crop was fungicide-treated rather than left untreated. This compares to the $0.93 \mathrm{Mt} \mathrm{CO}_{2}$ eq. saved by treating wheat with fungicides (Berry et al., 2008). However such differences also depend on other factors which affect oilseed rape and wheat yields, such as the cultivars used and their resistance to other pathogens. 
Furthermore, the estimated decrease in emissions $\mathrm{t}^{-1}$ seed associated with disease control for wheat is based on trial yield data and is therefore expected to be an underestimate, because yields obtained in plot experiments are greater than average UK yields.

\section{Effects of cultivar resistance}

There were yield differences between resistant and susceptible cultivars in HGCA trials in all years. Cultivars susceptible to $P$. brassicae on average yielded $4.43 \mathrm{t} \mathrm{ha}^{-1}$ while resistant cultivars yielded $4.63 \mathrm{t} \mathrm{ha}^{-1}$ in harvest years 2004-2007. This diseaseinduced yield loss from using cultivars susceptible to $P$. brassicae of $0.2 \mathrm{t} \mathrm{ha}^{-1}(4.3 \%)$ was equivalent to a difference in emissions between $753 \mathrm{~kg} \mathrm{CO}_{2}$ eq. $\mathrm{t}^{-1}$ for susceptible and $721 \mathrm{~kg} \mathrm{CO}_{2}$ eq. $\mathrm{t}^{-1}$ for resistant cultivars, with a net saving of $32 \mathrm{~kg} \mathrm{CO}_{2}$ eq. $\mathrm{t}^{-1}$ from growing resistant cultivars (Fig. 6a). The most significant benefit was $61 \mathrm{~kg}$ $\mathrm{CO}_{2}$ eq. $\mathrm{t}^{-1}$ in 2006 while 2004 was the only year where the resistant cultivars were associated with more emissions $\left(762 \mathrm{~kg} \mathrm{CO}_{2}\right.$ eq. $\left.\mathrm{t}^{-1}\right)$ than susceptible cultivars $(752 \mathrm{~kg}$ $\mathrm{CO}_{2}$ eq. $\mathrm{t}^{-1}$ ). For phoma stem canker, the mean yields were $3.84 \mathrm{t} \mathrm{ha}^{-1}$ and $3.95 \mathrm{t} \mathrm{ha}^{-1}$ for susceptible and resistant cultivars, respectively. Thus the yield loss for cultivars susceptible to L. maculans averaged at $0.11 \mathrm{t} \mathrm{ha}^{-1}(2.8 \%)$. These yields were equivalent to emissions of $869 \mathrm{~kg} \mathrm{CO} 2$ eq. $\mathrm{t}^{-1}$ and $845 \mathrm{~kg} \mathrm{CO} 2$ eq. $\mathrm{t}^{-1}$, with a net benefit of $24 \mathrm{~kg} \mathrm{CO}_{2}$ eq. $\mathrm{t}^{-1}$ from growing resistant cultivars (Fig. 6b). There were variations in the emission benefits of resistance over the four year period; benefits were smaller in $2004\left(13 \mathrm{~kg} \mathrm{CO}_{2}\right.$ eq. $\left.\mathrm{t}^{-1}\right), 2005\left(17 \mathrm{~kg} \mathrm{CO}_{2}\right.$ eq. $\left.\mathrm{t}^{-1}\right)$ and $2006\left(2 \mathrm{~kg} \mathrm{CO}_{2}\right.$ eq. $\left.\mathrm{t}^{-1}\right)$ than in 2007 (73 kg CO2 eq. $\mathrm{t}^{-1}$ ). Use of these yield differences between resistant and susceptible cultivars to estimate effects of resistance on GHG emissions greatly underestimated the effects of disease resistance, since yield differences between cultivars can be attributed to many different factors, including the differences in yield potential between cultivars, susceptibility of cultivars to other pathogens and the regional adaptation of cultivars to locations of the experiments. Such factors probably minimised the effects that resistance had on yield loss; however the resistant cultivars still yielded more and were associated with less GHG emissions than susceptible cultivars, irrespective of these factors.

(Figure 6 near here) 


\section{Economic evaluation}

Winter oilseed rape is a profitable crop in the UK (Spink et al., 2009; Table 2). Economic losses occur only when there is a combination of low prices and low yield (e.g. $<£ 215$ and $2.3 \mathrm{tha}^{-1}$ or $<£ 183$ when the seed yield is $2.7 \mathrm{t} \mathrm{ha}^{-1}$ ) (Table 2). It was assumed that there were constant input costs of $£ 495$ and the price used for winter oilseed rape was the Nov-09 MATIF Rapeseed futures price of £294. The gross margins for fungicide-treated and untreated crops were $£ 778$ and $£ 638$, respectively. Therefore there was a net benefit of $£ 140 \mathrm{ha}^{-1}$ from the use of fungicides. For cultivar resistance, the gross margin for cultivars resistant to $P$. brassicae (in the northern region where light leaf spot was the main disease) was $£ 866 \mathrm{ha}^{-1}$ while for susceptible cultivars it was $£ 807 \mathrm{ha}^{-1}$ with a net benefit of $£ 59 \mathrm{ha}^{-1}$. In the case of resistance to $L$. maculans (in the southern region where phoma stem canker was the main disease), the average gross margins were $£ 666 \mathrm{ha}^{-1}$ for resistant cultivars and $£ 634 \mathrm{ha}^{-1}$ for susceptible cultivars, a difference of $£ 32 \mathrm{ha}^{-1}$.

\section{(Table 2 near here)}

To maintain the UK production at the same level as in 2007 (2.1Mt, Anonymous, 2008b), were winter oilseed rape to be fungicide untreated, more arable land would be needed. The crop areas required to sustain 2007 UK production were estimated using the yield loss of $9.1 \%$ to be 680,000 ha if the crops were sprayed with fungicides and 748,000 ha if they were untreated. The difference of 68,000 ha represents land that could otherwise be put to a different uses, such as to grow more food or biofuel crops or as a wildlife habitat. In the other years investigated, the land areas required to produce the total UK oilseed rape production (1.89 Mt in 2006, 1.9 Mt in 2005 and $1.61 \mathrm{Mt}$ in 2004) (Anonymous, 2008b) with or without fungicide applications were 573,000 ha or 631,000 ha in $2006,575,000$ ha or 663,000 ha in 2005 and 554,000 ha or 664,000 ha in 2004. The differences were 58,000 ha, 91,000 ha and 110,000 ha, respectively, in those years, with an average additional area of 77,000 ha per year required if the oilseed rape crop was not treated with any fungicides.

The financial losses from leaving the crop untreated with fungicides were estimated at $£ 51 \mathrm{M}$ (2007), £38M (2006), £33M (2005) and $£ 33 \mathrm{M}$ (2004). The 2008 
losses of $£ 68 \mathrm{M}$ were calculated using the provisional Defra harvest results, which did not include oilseed rape grown on set-aside land; they are therefore underestimates. The five year potential losses if all oilseed rape crops were left untreated were $£ 224 \mathrm{M}$ (i.e. an average annual loss of $£ 45 \mathrm{M}$ ). An annual financial estimation of losses was also done by using annual percentages of crop lost to disease, which ranged from $9.1 \%$ in $2007,9.3 \%$ (2006), $13.3 \%$ (2005) to $13.9 \%$ (2004). The losses were estimated at $£ 41 \mathrm{M}, £ 31 \mathrm{M}, £ 39 \mathrm{M}$ and $£ 40 \mathrm{M}$ for the respective years with a cumulative financial loss of $£ 152 \mathrm{M}$. This represents an estimated loss of $£ 38 \mathrm{M}$ per annum during this 4- year period if no fungicides were applied to winter oilseed rape crops.

\section{Discussion}

These results demonstrate how disease control in arable crops can make a contribution to climate change mitigation as well as to global food security. They suggest that disease control should be included amongst other policy options for decreasing GHG emissions from agriculture (Smith et al., 2007, 2008; Gregory, 2008). Given the need to optimise food production in northern Europe in response to climate change threats to global food security (Stern, 2007), there are also benefits from controlling diseases in winter oilseed rape in terms of decreased GHG per tonne of crop produced. These decreases are especially associated with more efficient use of nitrogen fertiliser applied to the crop (Glendining et al., 2008). Furthermore, the climate change mitigation benefits associated with disease control in UK winter oilseed rape are considerably greater than those associated with disease control in winter wheat (Berry et al., 2008). It is also likely that there will be climate change mitigation benefits from disease control in other arable crops, both in developed and in developing countries, although the mitigation benefits are likely to be less where yields are less and nitrogen fertiliser application rates are less.

It is likely that the mitigation benefits of breeding for resistance to the pathogens that cause crop diseases are considerably greater than those estimated in this work, because it was not possible to clearly separate them from other factors. Furthermore, crop disease resistance is an ideal method of disease control, both high input - high yield crops (e.g. in the UK) where it decreases the need for additional field operations 
(e.g. to apply fungicide) and in low input - low yield crops (e.g. in sub-Saharan Africa) where it is not cost-effective to use fungicides. Nevertheless such resistance is beneficial in terms of climate change mitigation only if it is durable and can be used in crops for a number of cropping seasons. By contrast, it took some 10 years to introduce resistance genes against L. maculans from Brassica rapa ssp. sylvestris into commercial oilseed rape cultivars that were released in Australia in 2000 and this resistance had been rendered ineffective by 2002, as a result of changes for virulence in the pathogen population (Sprague et al., 2006). Had the GHG emissions associated with the 10 years of breeding before the release of these cultivars been estimated, it is likely that this resistance would have had no benefit in terms of climate change mitigation. This example demonstrates the need for careful breeding and deployment of disease resistance in cultivars so that the resistance is durable (Stukenbrock \& McDonald, 2008) and can contribute not only to sustainable crop production but also to climate change mitigation. There are also benefits associated with disease control using fungicides that contribute to climate change mitigation in high input systems, as in this work with winter oilseed rape and that of Berry et al. (2008) with winter wheat. However, it is important to remember that recent European Parliament legislation (Directive 91/414, http://ec.europa.eu/food/plant/protection/index_en.htm) may mean that fewer fungicides are available to control winter oilseed diseases in the future.

In a world where 800 million people do not have sufficient food to eat (Strange \& Scott, 2005) and climate change is exacerbating the food security problems for communities farming in marginal environments (Morton, 2007, Schmidhuber \& Tubiello, 2007), it is essential to develop better strategies for controlling crop diseases as a contribution to global food security (Pinstrup-Andersen, 2009). There is an urgent need to decrease current global average crop losses to diseases from 16\% (Oerke, 2006), especially since disease losses are often much greater in crops grown by subsistence farmers in marginal areas. Disease resistance breeding, fungicides and cultural methods can all contribute to strategies to decrease disease losses but they need to be carefully integrated into disease management strategies appropriate for the farming system operating in the region. As a contribution to global food security in the face of climate change, there is a need to maximise crop production in northern Europe (Stern, 2007, www.climatecongress.ku.dk) by optimising disease control. Such strategies will also help to maintain the yields and profitability of European 
farms and thus provide food security for farming families, who might otherwise stop food production and thus worsen global food security problems.

There is also a need to anticipate future disease-induced losses and act now to prevent them. For example, the phoma stem canker pathogen L. maculans is currently a threat to production of $8 \mathrm{M}$ ha of oilseed rape grown in China, mostly by subsistence farmers (Fitt et al., 2006, 2008). This pathogen, which has been spreading globally, is not currently present in China, although Chinese cultivars are extremely susceptible to it when they are grown in Europe or Australia. By using models of the spread of $L$. maculans across Canada from 1983 to 1998 to predict the future spread across China, it was estimated that an epidemic will cost China $£ 3500 \mathrm{M}$ and cause much hardship for subsistence farming families. It was estimated that the combined cost of shortterm (e.g. quarantine, education of farmers to recognise disease symptoms, disease surveys) and long-term (e.g. resistance breeding) strategies to prevent entry and spread of the pathogen over a 10 -year period is less than $1 / 1000^{\text {th }}$ of the cost of an epidemic. This example illustrates the urgent need to develop integrated strategies for controlling crop diseases in the face of threats to crop production, including those associated with climate change, to sustain arable crop production and ensure global food security.

\section{Acknowledgements}

The authors are grateful for the funding and information provided by HGCA and the UK Department for Environment, Food and Rural Affairs, including the Sustainable Arable LINK projects CORDISOR and CLIMDIS. Rothamsted Research is an institute of the UK Biotechnology and Biological Sciences Research Council. We are grateful to Gordon Dailey and Peter Street for advice about this work and to James Townsend for assistance with the paper.

\section{References}

Anderson, P.K., Cunningham, A.A., Patel, N.G., Morales, F.J., Epstein, P.R., Daszak, P. (2004) Emerging infectious diseases of plants: pathogen pollution, climate 
change and agrotechnology drivers. Trends in Ecology and Evolution 19, 535544. doi: 10.1016/j.tree.2004.07.021

Anonymous (2000) Fertiliser recommendations for agricultural and horticultural crops (RB209) (seventh edition), UK Ministry of Agriculture, Fisheries \& Food (MAFF). On WWW at http://www.defra.gov.uk/farm/environment/landmanage/nutrient/fert/rb209/index.htm Accessed March 2009.

Anonymous (2007a) British Survey of Fertiliser Practice. Fertiliser Use on Farm Crops for Crop Year 2006. On WWW at http://www.defra.gov.uk/ farm/environment/landmanage/nutrient/pdf/bsfp2006.pdf (accessed March 2009). Anonymous (2007b) The National Non-Food Crops Centre (NNFCC) Environmental Assessment Tool for Biomaterials (Defra project NF0614) On WWW at http://www.nnfcc.co.uk/metadot/index.pl?id=2461;isa=Category;op=show (accessed March 2009).

Anonymous (2008a) HGCA Recommended List Plus On WWW at http://www.hgca.com/varieties/rl-plus/ (accessed March 2009).

Anonymous (2008b) Defra: Cereals and oilseed rape production estimates: 2008 Harvest. On WWW at https://statistics.defra.gov.uk/esg/statnot/ cps_osr_mincrop.pdf (accessed September 2008).

Berry, P.M., Kindred, D.R., Paveley, N.D. (2008) Quantifying the effects of fungicides and disease resistance on greenhouse gas emissions associated with wheat production. Plant Pathology 57, 1000-1008. doi: 10.1111/j.13653059.2008.01899.x

Booth, E., Booth, J., Cook, P., Ferguson, B., Walker, K. (2005) Economic Evaluation of Biodiesel Production from Oilseed Rape grown in North and East Scotland. 117 pp. On WWW at http://www.angus.gov.uk/ac/documents/sacreport.pdf (accessed March 2009.

Boys, E.F., Roques, S.E., Ashby, A.M., Evans, N., Latunde-Dada, A.O., Thomas, J.E., West, J.S., Fitt, B.D.L. (2007). Resistance to infection by stealth: Brassica napus (winter oilseed rape) and Pyrenopeziza brassicae (light leaf spot). European Journal of Plant Pathology 118:307-321. doi: 10.1007/s10658-0079141-9

Butterworth, M.H., Semenov, M.A., Barnes, A., Moran, D., West, J.S., Fitt, B.D.L. (2009). North-south divide; contrasting impacts of climate change on crop yields in Scotland and England. Journal of the Royal Society Interface (in press). 
Chakraborty, S., Tiedemann, A.V., Teng, P.S. (2000) Climate change: potential impact on plant diseases. Environmental Pollution 108, 317-326. doi: 10.1016/S0269-7491(99)00210-9

De Klein, C.A.M., Novoa, R.S.A., Ogle, S.M., Smith, K.A., Rochette, P., Wirth, T.C., McConkey, B.G., Mosier, A., Rypdal, K., Walsh, M., Williams, S.A. (2006) $\mathrm{N}_{2} \mathrm{O}$ emissions from managed soils and $\mathrm{CO}_{2}$ emissions from lime and urea application. Chapter 11 In: Eggleston HS, Buendia L, Miwa K, Ngara T, Tanabe K (eds). IPCC 2006, 2006 IPCC Guidelines for National Greenhouse Gas Inventories., Prepared by the National Greenhouse Gas Inventories Programme, IGES, Japan. On WWW at http://www.ipccnggip.iges.or.jp/public/2006gl/pdf/ 4_Volume4/V4_11_Ch11_N2O\&CO2.pdf (accessed March 2009).

Edwards, R., Larive, J., Mahieu, V., Rouveirolles, P. (2006). Well-to-Wheels Analysis of Future Automotive Fuels and Powertrains in the European Context. On WWW at http://ies.jrc.ec.europa.eu/well-to-wheels-analysis (accessed March 2009).

Evans, N., Baierl, A., Semenov, M.A., Gladders, P., Fitt, B.D.L. (2008) Range and severity of a plant disease increased by global warming. Journal of the Royal Society Interface 5, 525-531 doi: 10.1098/rsif.2008.1136

FAO (2007) Climate Change and Food Security: A Framework Document. Rome, FAO. On WWW at http://www.fao.org/docrep/010/k2595e/k2595e00.htm. (accessed March 2009).

FAO (2009) Food Security. On WWW at http://www.fao.org/climatechange/ 49357/en/ (accessed March 2009).

Fitt, B.D.L., Brun, H,, Barbetti, M.J., Rimmer, S.R. (2006) World-wide importance of phoma stem canker (Leptosphaeria maculans and L. biglobosa) on oilseed rape (Brassica napus). European Journal of Plant Pathology 114, 3-15. doi:10.1007/s10658-005-2233-5

Fitt, B.D.L., Hu, B.C., Li, Z.Q., Liu, S.Y., Lange, R.M., Kharbanda, P.D., Butterworth, M.H., White RP (2008) Strategies to prevent spread of Leptosphaeria maculans (phoma stem canker) onto oilseed rape crops in China; costs and benefits. Plant Pathology 57, 652-664. doi: 10.1111/j.13653059.2008.01841.x

Frow, E., Ingram, D., Powell, W., Steer, D., Vogel, J., Yearley, S. (2009) The politics of plants. Food Security 1, 17-23. doi: 10.1007/s12571-008-0007-6 
Garrett, K.A., Dendy, S.P., Frank, E.E., Rouse, M.N., Travers, S.E. (2006) Climate change effects on plant disease: genomes to ecosystems. Annual Review of Phytopathology 44, 489-509. doi:10.1146/annurev.phyto.44.070505.143420

Garthwaite, D.G., Thomas, M.R., Heywood, E., Battersby, A. (2006). Pesticide Usage Survey Report 213: Arable crops in Great Britain 2006. Department for Environment, Food \& Rural Affairs (UK) \& Scottish Executive Environment \& Rural Affairs Department. 116 pp. On WWW at http://www.csl.gov.uk/ newsAndResources/resourceLibrary/articles/puskm/arable2006.pdf （accessed March 2009).

Glendining, M.J., Dailey, A.G., Williams, A.G., van Evert, F.K., Goulding, K.W.T., Whitmore, A.P. (2008) Is it possible to increase the sustainability of arable and ruminant agriculture by reducing inputs? Agricultural Systems 99, 117-125. doi: 10.1016/j.agsy.2008.11.001

Gregory, P.J. (2008) Mitigating climate change: energy, carbon and nitrogen on the farm. HGCA R\&D Conference 'Arable Cropping in a Changing Climate', 23-24 January 2008, Belton Woods, Lincs. pp. 12-20. On WWW at http://www.hgca.com/document.aspx?fn=load\&media_id=4105\&publicationId=0 (accessed March 2009).

Gregory, P.J., Johnson, S.N., Newton, A.C., Ingram, J.S. (2009) Integrating pests and pathogens into the climate change/food security debate. Journal of Experimental Botany (in press).

Jackson, J., Li, Y., Passant, N., Thistlethwaite, G., Thomson, A., Cardenas, L. (2007) Greenhouse Gas Inventories for England, Scotland, Wales and Northern Ireland: 1990-2005. Didcot, UK, AEA Environment and Technology, 40 pp. On WWW at http://nora.nerc.ac.uk/2230/ (accessed March 2009).

Mortimer, N.D., Elsayed, M.A., Horne, R.E. (2004). Energy and greenhouse gas emissions for bioethanol production from wheat grain and sugar beet. Sheffield UK: Sheffield Hallam University. Final Report 23/1

Morton, J.F., 2007. The impact of climate change on smallholder and subsistence agriculture. Proceedings of the National Academy of Science of the United States of America 104, 19680-19685. doi: 10.1073/pnas.0701855104

Nix, J. (2007) Farm Management Pocketbook 2008. The John Nix farm management pocketbook Edition 38, 270 pp. The Anderson Centre; Melton Mowbray; UK. 
Oerke, E.C. (2006) Crop losses to pests. Journal of Agricultural Science 144, 31-43. doi: $10.1017 / \mathrm{S} 0021859605005708$

Pinstrup-Andersen, P. (2009) Food security: definition and measurement. Food Security 1, 2-7. doi: 10.1007/s12571-008-0002-y

Schmidhuber, J., Tubiello, F.N. (2007) Global food security under climate change. Proceedings of the National Academy of Science of the United States of America 104, 19703-19708. doi: 10.1073/pnas.0701976104

Smith, P., Martino, D., Cai, Z., Gwary, D., Janzen, H., Kumar, P., McCarl, B., Ogle, S., O’Mara, F., Rice, C., Scholes, B., Sirotenko, O., Howden, M., McAllister, T., Pan, G., Romanenkov, V., Schneider, U., Towprayoon, S. (2007) Policy and technological constraints to implementation of greenhouse gas mitigation options in agriculture. Agriculture, Ecosystems and Environment 118:6-28. doi: 10.1016/j.agee.2006.06.006

Smith, P., Martino, D., Cai, Z., Gwary, D., Janzen, H., Kumar, P., McCarl, B., Ogle, S., O’Mara, F., Rice, C., Scholes, B., Sirotenko, O., Howden, M., McAllister, T., Pan, G., Romanenkov, V., Schneider, U., Towprayoon, S., Wattenbach, M., Smith, J. (2008) Greenhouse gas mitigation options in agriculture. Philosophical Transactions of the Royal Society B 363, 789-813. doi: 10.1098/rstb.2007.2184

Spink, J., Street, P., Sylvester-Bradley, R., Berry, P. (2009) The potential to increase productivity of wheat and oilseed rape in the UK. Report to the Government Chief Scientific Adviser, Professor John Beddington. On WWW at http://www.dius.gov.uk/partner_organisations/office_for_science/science_in_gov ernment/key_issues/food_security/ /media/5C4E476342334B608B748767805B1 115.ashx (accessed March 2009).

Sprague, S.J., Balesdent, M.H., Brun, H., Hayden, H.L., Marcroft, S.J., Pinochet, X., Rouxel, T., Howlett, B.J. (2006) Major gene resistance in Brassica napus (oilseed rape) is overcome by changes in virulence of populations of Leptosphaeria maculans in France and Australia. European Journal of Plant Pathology 115, 3340. doi: 10.1007/s10658-005-2108-9

Stern, N. (2007) The economics of climate change: the Stern review. Cambridge, UK: Cambridge University Press. 692 pp.

Strange, R.N., Scott, P.R. (2005) Plant disease: a threat to global food security. Annual Review of Phytopathology 43, 83-116. doi: 10.1146/annurev.phyto. 43.113004.133839 
Stukenbrock, E.H., McDonald, B.A. (2008) The origins of plant pathogens in agroecosystems. Annual Review of Phytopathology 46, 75-100. doi: 10.1146/ annurev.phyto.010708.154114

West, J.S., Fitt, B.D.L., Rogers, S.L., White, R.P., Todd, A.D., Latunde-Dada, A.O., Gladders, P., Thomas, J., Booth, E., Jennaway, R., Clarke, M., Padbury, N., Bowman, J., Nightingale, M., Werner, P., Jellis, G. (2008) Components of resistance to diseases in winter oilseed rape cultivars: CORDISOR. HGCA Project Report No 446, HGCA, London. 71 pp.

Williams, A.G., Audsley, E., Sandars, D.L. (2006). Determining the environmental burdens and resource use in the production of agricultural and horticultural commodities. Defra Final report, project IS0205. Defra, London. 
Table 1 Inputs used in the production of 1 ha of a UK winter oilseed rape crop, their application rates and their greenhouse gas (GHG) emission factors.

\begin{tabular}{|c|c|c|c|c|}
\hline Input & $\begin{array}{l}\text { Application } \\
\text { rate used }\end{array}$ & Reference & $\begin{array}{l}\text { Emission } \\
\text { factor }^{a}\end{array}$ & Reference \\
\hline $\begin{array}{l}\mathrm{N} \text { fertiliser (in } \\
\text { manufacture) }\end{array}$ & $202 \mathrm{~kg} \mathrm{ha}^{-1}$ & $\begin{array}{l}\text { Anonymous } \\
\text { (2007a) }\end{array}$ & 7.11 & $\begin{array}{l}\text { Anonymous } \\
\text { (2007b) }\end{array}$ \\
\hline $\begin{array}{l}\mathrm{N} \text { fertiliser } \\
\left(\mathrm{N}_{2} \mathrm{O}\right) \text { (after } \\
\text { application) }\end{array}$ & $202 \mathrm{~kg} \mathrm{ha}^{-1}$ & $\begin{array}{l}\text { Anonymous } \\
\text { (2007a) }\end{array}$ & 6.16 & $\begin{array}{l}\text { De Klein et al. } \\
(2006)\end{array}$ \\
\hline $\mathrm{K}$ fertiliser $\left(\mathrm{K}_{2} \mathrm{O}\right)$ & $42 \mathrm{~kg} \mathrm{ha}^{-1}$ & $\begin{array}{l}\text { Anonymous } \\
\text { (2007a) }\end{array}$ & 1.76 & $\begin{array}{l}\text { Anonymous } \\
\text { (2007b) }\end{array}$ \\
\hline $\begin{array}{l}\mathrm{P} \text { fertiliser } \\
\left(\mathrm{P}_{2} \mathrm{O}_{5}\right)\end{array}$ & $39 \mathrm{~kg} \mathrm{ha}^{-1}$ & $\begin{array}{l}\text { Anonymous } \\
\text { (2007a) }\end{array}$ & 1.86 & $\begin{array}{l}\text { Anonymous } \\
\text { (2007b) }\end{array}$ \\
\hline $\begin{array}{l}\text { Field operations } \\
\text { energy use }\end{array}$ & $5129 \mathrm{MJ} \mathrm{ha}^{-1}$ & $\begin{array}{l}\text { Williams et al. } \\
(2006)\end{array}$ & 0.0864 & $\begin{array}{l}\text { Edwards et al. } \\
(2006)\end{array}$ \\
\hline $\begin{array}{l}\text { Lime (ground } \\
\text { limestone) }\end{array}$ & $409 \mathrm{~kg} \mathrm{ha}^{-1}$ & $\begin{array}{l}\text { Anonymous } \\
\text { (2007a) }\end{array}$ & 0.15 & $\begin{array}{l}\text { Anonymous } \\
\text { (2007b) }\end{array}$ \\
\hline Fungicides $^{b}$ & $0.42 \mathrm{~kg}$ a.i. ha $^{-1}$ & $\begin{array}{l}\text { Garthwaite et al. } \\
\text { (2006) }\end{array}$ & 3.28 & $\begin{array}{l}\text { Anonymous } \\
\text { (2007b) }\end{array}$ \\
\hline Herbicides $^{b}$ & $1.6 \mathrm{~kg}$ a.i. $\mathrm{ha}^{-1}$ & $\begin{array}{l}\text { Garthwaite et al. } \\
\text { (2006) }\end{array}$ & 5.04 & $\begin{array}{l}\text { Anonymous } \\
\text { (2007b) }\end{array}$ \\
\hline Insecticides $^{b}$ & $0.03 \mathrm{~kg}$ a.i. $\mathrm{ha}^{-1}$ & $\begin{array}{l}\text { Garthwaite et al. } \\
\text { (2006) }\end{array}$ & 4.71 & $\begin{array}{l}\text { Anonymous } \\
\text { (2007b) }\end{array}$ \\
\hline Seed & $5 \mathrm{~kg} \mathrm{ha}^{-1}$ & $\begin{array}{l}\text { Williams et al. } \\
(2006)\end{array}$ & 0.0632 & $\begin{array}{l}\text { Mortimer et al. } \\
(2004)\end{array}$ \\
\hline
\end{tabular}

$\mathrm{MJ}^{-1}$

${ }^{\mathrm{b}}$ a.i. active ingredient 
Table 2 Gross margin analysis in relation to winter oilseed rape yield (t/ha) and price $(£ / t)$ assuming fixed input costs of $£ 495$ per ha.

\begin{tabular}{|c|c|c|c|c|c|c|c|c|c|}
\hline Price & \multicolumn{9}{|c|}{ Gross margin $(\mathfrak{E} / \mathrm{ha})^{a}$} \\
\hline $\begin{array}{l}\text { Yield } \\
\text { (t/ha) }\end{array}$ & 2.3 & 2.7 & 3.1 & 3.5 & 3.9 & 4.3 & 4.7 & 5.1 & 5.5 \\
\hline 160 & -127 & -63 & 1 & 65 & 129 & 193 & 257 & 321 & 385 \\
\hline 200 & -35 & 45 & 125 & 205 & 285 & 365 & 445 & \begin{tabular}{|l|}
525 \\
\end{tabular} & 605 \\
\hline 240 & 57 & 153 & 249 & 345 & 441 & 537 & 633 & 729 & 825 \\
\hline 280 & 149 & 261 & 373 & 485 & 597 & 709 & 821 & 933 & 1045 \\
\hline 320 & 241 & 369 & 497 & 625 & 753 & 881 & 1009 & 1137 & 1265 \\
\hline 360 & 333 & 477 & 621 & 765 & 909 & 1053 & 1197 & 1341 & 1485 \\
\hline 400 & 425 & 585 & 745 & 905 & 1065 & 1225 & 1385 & 1545 & \begin{tabular}{|l|l}
1705 \\
\end{tabular} \\
\hline
\end{tabular}

${ }^{\text {a }}$ A gross margin is the difference between gross income and total variable (running) costs for a farm activity. Variable costs include fuel, machinery costs, casual labour costs, disease, pest and weed control and harvesting costs. They are distinct from fixed costs such as the living expenses for the farmer's family and taxes. 


\section{Figure Legends}

Figure 1 Relationships between different stages in the collection and processing of information for analysis of the contribution of disease control in UK winter oilseed rape (WOSR) to decreasing greenhouse gas (GHG) emissions. (1) Rates of application of inputs to WOSR crops (Table 1) were multiplied by GHG emission factors to estimate GHG emissions per ha of WOSR (Fig. 2). (2) Yield data were collated from WOSR field experiments in which cultivars that were resistant/susceptible to Leptosphaeria maculans (phoma stem canker) or Pyrenopeziza brassicae (light leaf spot) were grown in plots with/without fungicide treatments. (3)These data were combined with GHG emissions data to estimate GHG emissions per t yield of WOSR (Fig. 3) and the effects of fungicide treatments (Figs 4 \& 5) and cultivar resistance to the two pathogens (Fig. 6) on GHG emissions. (4) Finally these data were analysed economically (Table 2).

Figure 2 Greenhouse gas emissions (GHG) related to different inputs in the production of 1 hectare of winter oilseed rape in the UK. These inputs include nitrogen, potash (69 $\mathrm{kg} \mathrm{CO}_{2}$ eq. ha-1) and phosphate fertilisers (78 $\mathrm{kg} \mathrm{CO}_{2}$ eq. ha- ${ }^{-1}$ ). For nitrogen fertilisers, GHG are released when they are manufactured $(1433 \mathrm{~kg} \mathrm{CO}$ eq. $\left.\mathrm{ha}^{-1}\right)$ and when they are applied $\left(1242 \mathrm{~kg} \mathrm{CO}_{2}\right.$ eq. ha $\left.{ }^{-1}\right)$. The other inputs are the emissions from seed production ( $2 \mathrm{~kg} \mathrm{CO} 2$ eq. ha-1), field operations such as tractor use $\left(443 \mathrm{~kg} \mathrm{CO}_{2}\right.$ eq. ha-1 $)$ and the manufacture of fungicides $\left(1.37 \mathrm{~kg} \mathrm{CO}_{2}\right.$ eq. ha $\left.{ }^{-1}\right)$, herbicides $\left(7.89 \mathrm{~kg} \mathrm{CO}_{2}\right.$ eq. ha $\left.{ }^{-1}\right)$, insecticides $\left(0.15 \mathrm{~kg} \mathrm{CO}_{2}\right.$ eq. ha-1) and lime $(60 \mathrm{~kg}$ $\mathrm{CO}_{2}$ eq. ha-1).

Figure 3 Relationship between yield of UK winter oilseed rape ( $\mathrm{t}$ ha ${ }^{-1}$ ) and greenhouse gas emissions (GHG) per tonne of seed produced. The GHG emissions per tonne are given in kilogramme equivalent of $\mathrm{CO}_{2}$ per tonne. The seed yield is the only parameter changed while other inputs are kept constant for these calculations.

Figure 4 Differences in greenhouse gas (GHG) emissions per tonne of yield between winter oilseed rape crops (means of 24-39 cultivars at 4-7 different sites) treated with

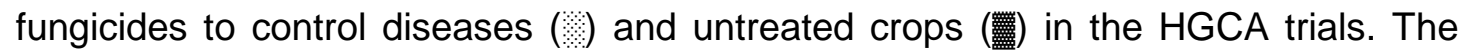
numbers of sites where the data were available for both treated and untreated crops were 5 (2004), 7 (2005), 6 (2006) and 4 (2007). The numbers of cultivars used in different years were 26 (2004), 39 (2005), 24 (2006) and 29 (2007). 
Figure 5 Differences in greenhouse gas (GHG) emissions per tonne of yield between winter oilseed rape crops treated with fungicides to control diseases ( $/$ ) and untreated crops (梆). Results are for field experiments done at Rothamsted (20052007) and by ADAS at Teversham (2005) and Boxworth (2006-2007). Rothamsted experiments tested 19 different cultivars in 2005 and 20 cultivars in 2006 and 2007, in all cases with three replicates of each untreated and treated plot (six plots per cultivar). ADAS experiments tested 20 cultivars with three replicates of each treated and untreated cultivar (6 plots) for 2005 and four replicates (8 plots) for 2006-2007.

Figure 6 (a) Differences in greenhouse gas (GHG) emissions per tonne of yield between winter oilseed rape cultivars that are resistant or susceptible to Pyrenopeziza brassicae (light leaf spot). The cultivars had HGCA resistance ratings of 1-6 (susceptible) or 7-9 (resistant). The data were based on HGCA trials in the north HGCA RL oilseed rape growing region of the UK (approximately north of the line joining Lancaster and Middlesbrough). The numbers of sites used for each year were 3 (2004), 3 (2005), 2 (2006) and 1 (2007). The numbers of susceptible cultivars were 8 (2004), 10 (2005), 13 (2006) and 16 (2007), whereas the numbers of resistant cultivars used were 9 (2004), 10 (2005), 5 (2006) and 4 (2007).

(b) Differences in GHG emissions released between winter oilseed rape cultivars that are resistant or susceptible to Leptosphaeria maculans (phoma stem canker). The cultivars had HGCA resistance ratings of 1-5 (susceptible) or 6-9 (resistant). The data were entirely based on HGCA trials in the south HGCA RL oilseed rape growing region of the UK (approximately south of the line joining Lancaster and Middlesbrough). The numbers of sites used for each year were 2 (2004), 4 (2005), 4 (2006) and 3 sites (2007). The numbers of susceptible cultivars were 6 (2004), 11 (2005), 14 (2006) and 16 (2007), whereas the numbers of resistant cultivars used were 13 (2004), 9 (2005), 5 (2006) and 4 (2007).

The HGCA oilseed rape regional map is shown on the web-site for the HGCA Recommended List 2009/10 for cereals and oilseeds (www.hgca.com). 
Figure 1

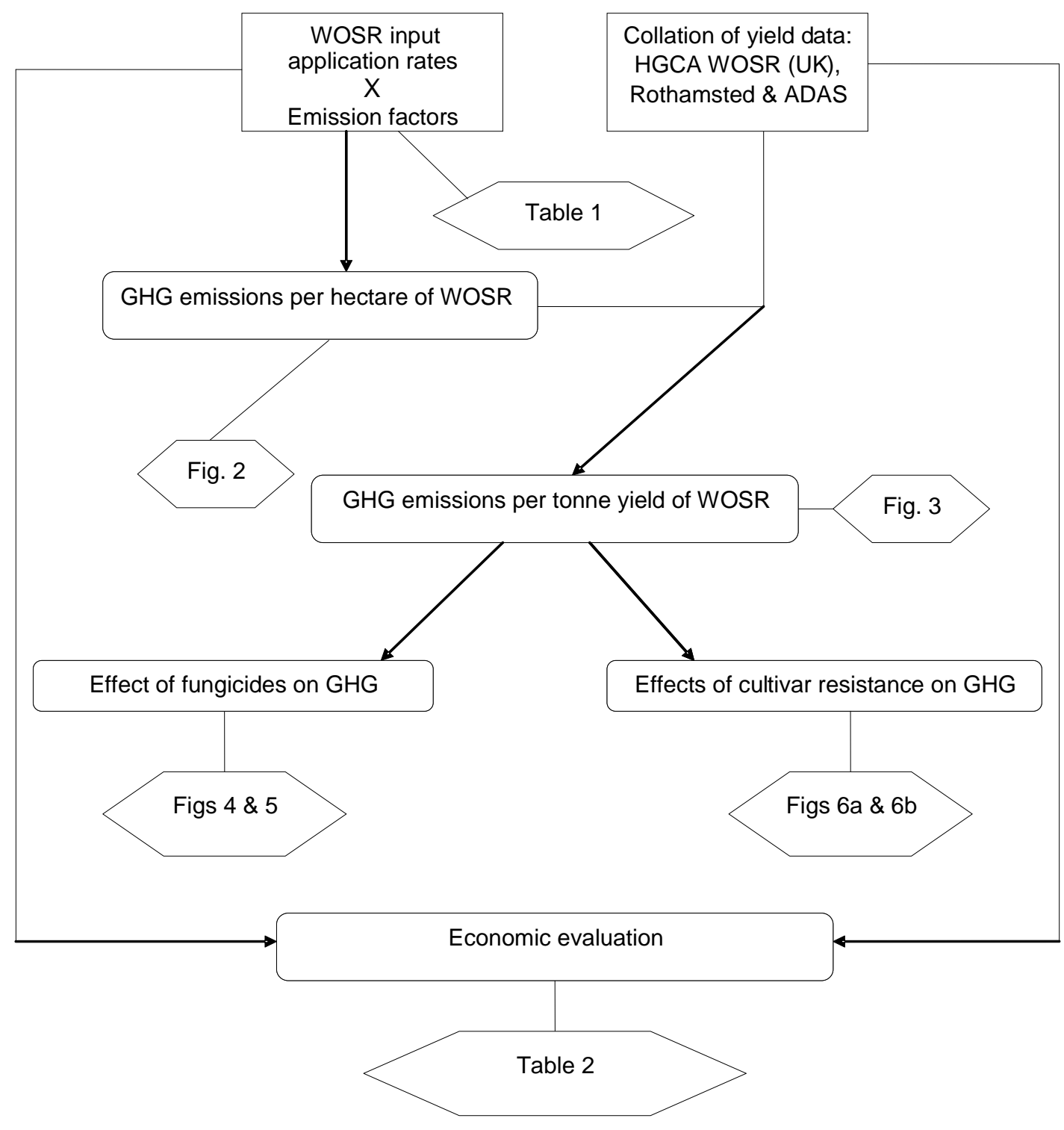


Figure 2

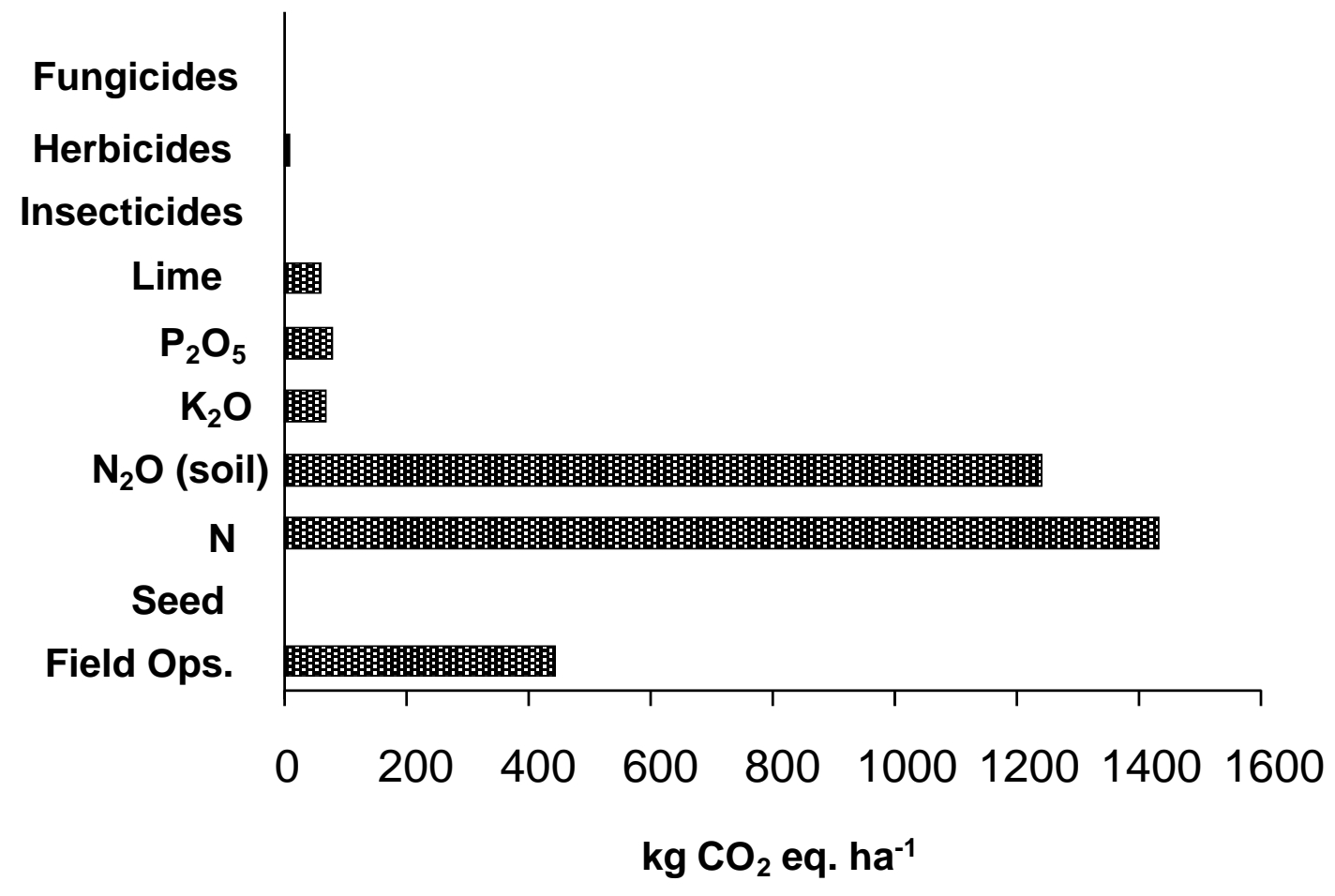


Figure 3

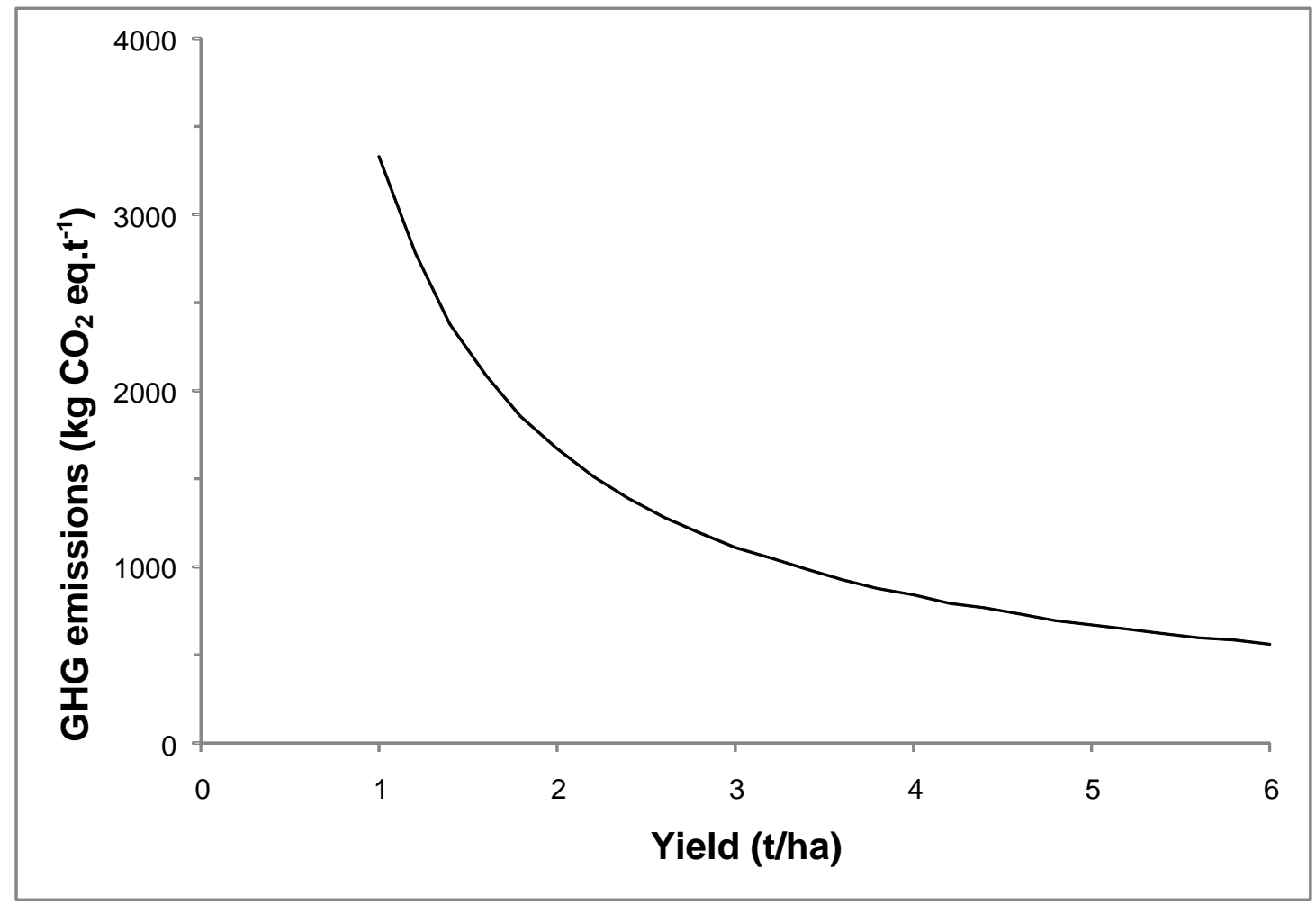


Figure 4

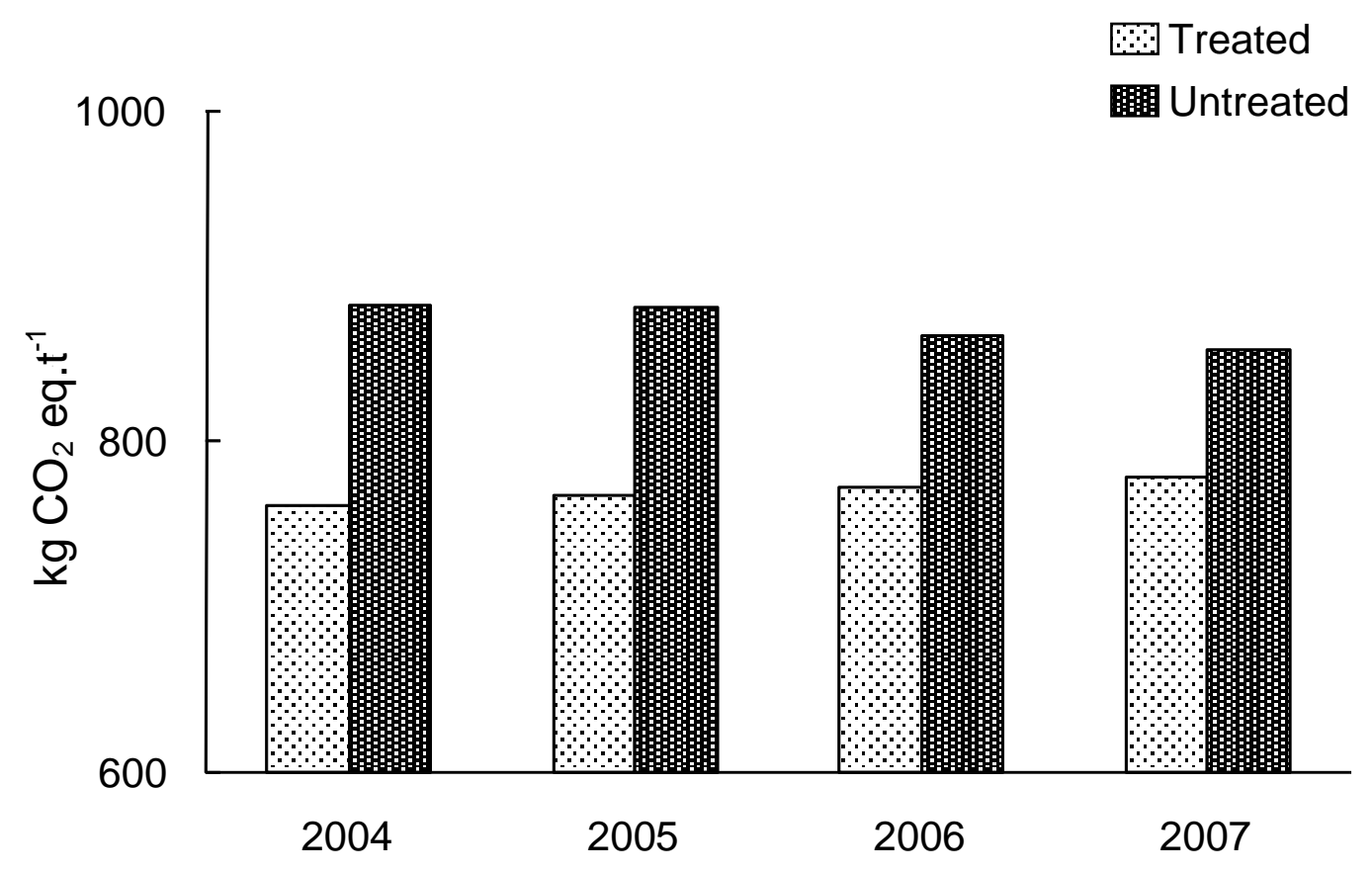


Figure 5

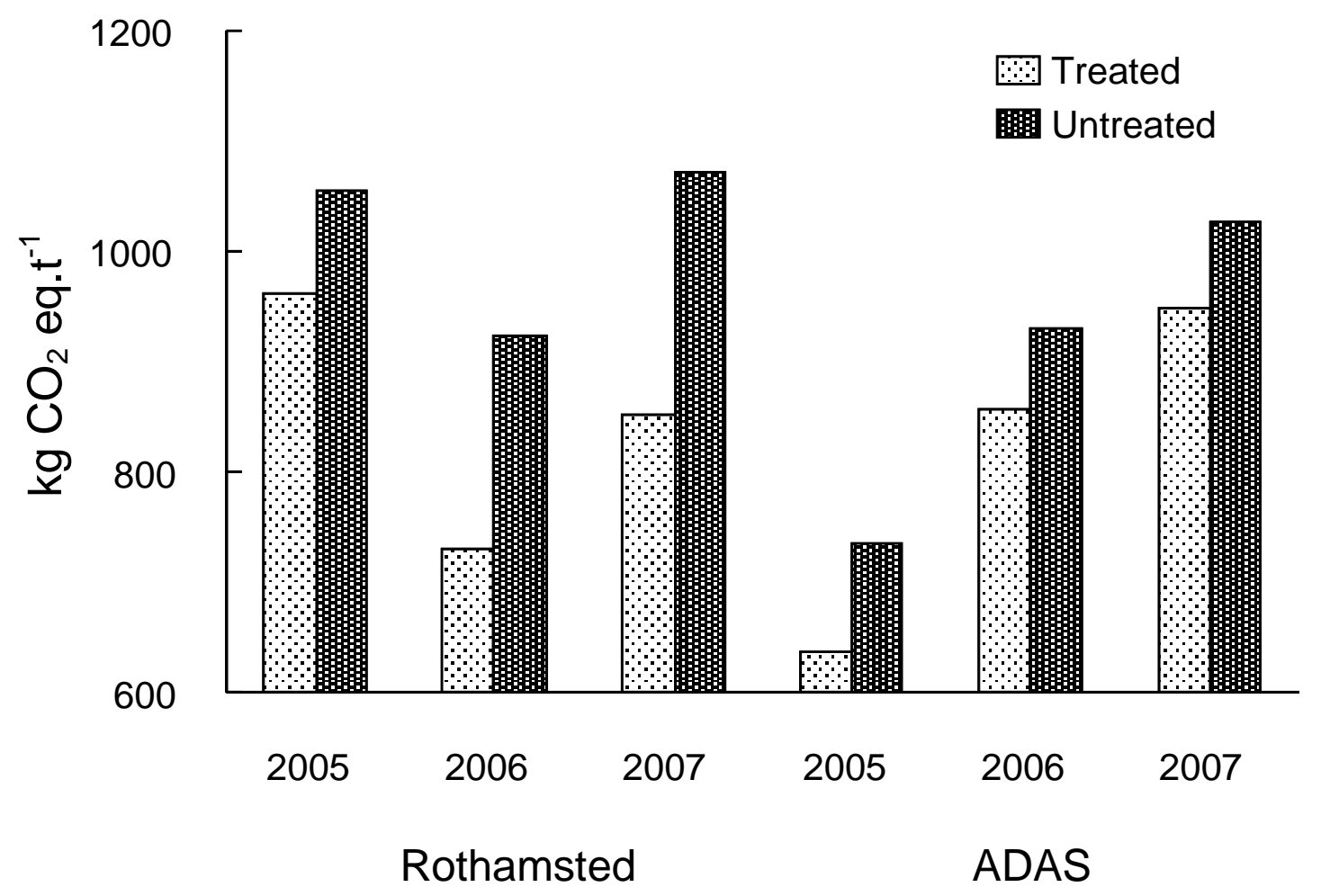


Figure 6

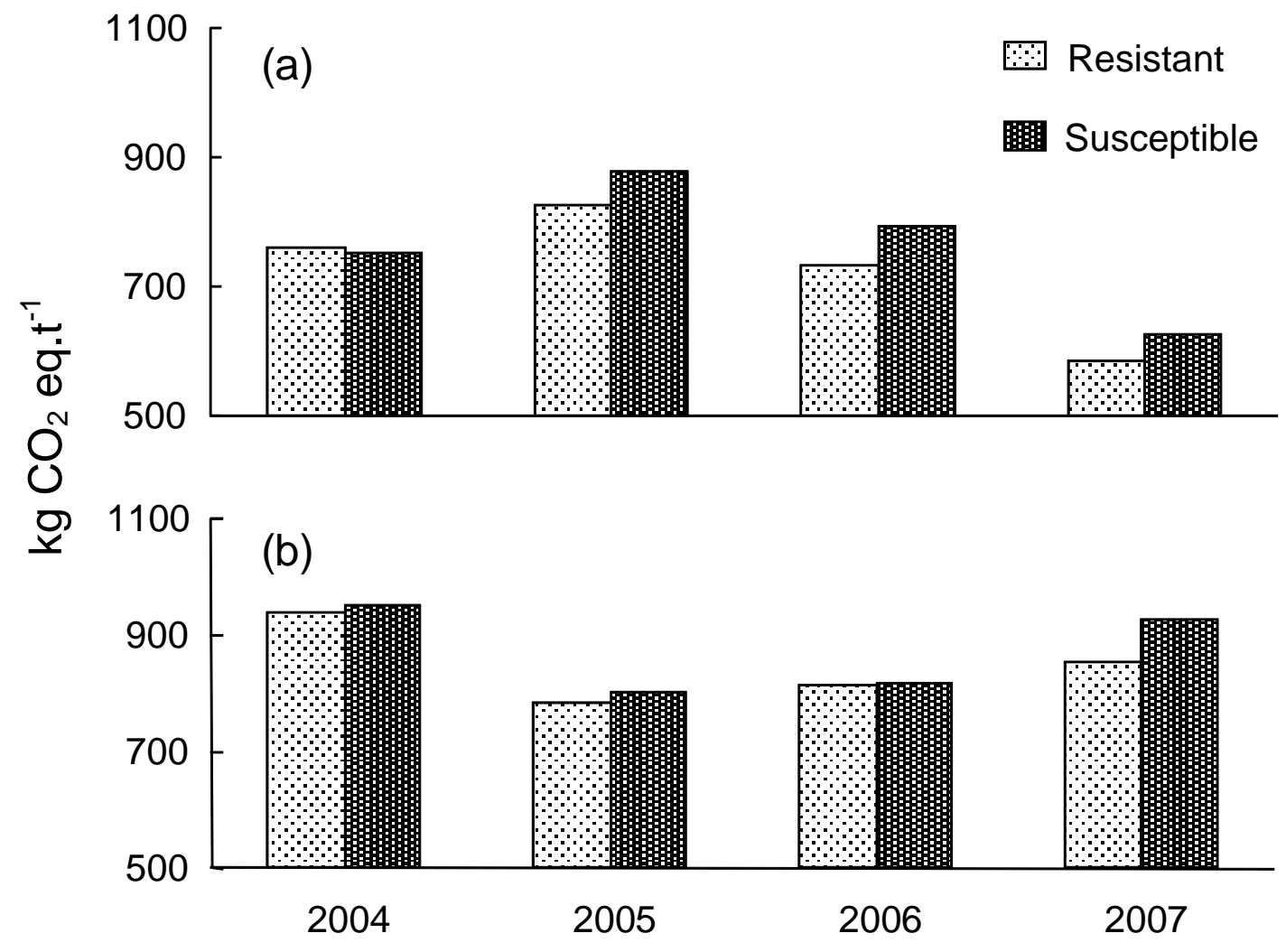

